\title{
PELAKSANAAN FUNGSI ORGANISASI KARANG TARUNA DI DESA TAPUHAKA KECAMATAN KABAENA TIMUR
}

\author{
Omi Fibrianti, Abdul Halim Momo, Nerlin \\ Jurusan Pendidikan Pancasila dan Kewarganegaraan \\ Fakultas Keguruan dan Ilmu Pendidikan \\ Universitas Halu Oleo \\ Email:omi.fibrianti02@gmail.com,abdulhalimmomo@gmail.com,nerlin@uho.ac.id
}

\begin{abstract}
Abstrak: Tujuan penelitian ini yaitu untuk mengetahui pelaksanaan fungsi organisasi Karang Taruna Damalawa dalam menyelenggarakan kesejahteraan sosial. Metode penelitian ini adalah deskriptif kualitatif. Subjek penelitian ini adalah informan tokoh masyarakat, Kepala Desa, dan responden anggota Karang Taruna. Teknik pengumpulan data terdiri dari Observasi, wawancara, dokumentasi. Teknik analisis data adalah reduksi data, penyajian data, penarikan kesimpulan dan verifikasi. Hasil Penelitian ini menunjukan bahwa dalam pelaksanaan fungsi organisasi Karang Taruna Damalawa melakukan berbagai kegiatan atau aktivitas dalam berupaya menyelenggarakan kesejahteraan sosial yang meliputi: rehabilitasi, pemberdayaan sosial, perlindungan sosial dan diklat setiap anggota masyarakat terutama generasi muda dirangkai dalam berbagai kegiatan diantaranya rapat terbuka, bakti sosial, pengembangan objek wisata, kesenian dan olahraga, pelatihan dan pembinaan, kegiatan peringatan hari-hari besar dan terlibat langsung dalam memberikan bantuan langsung. Kesimpulan pelaksanaan fungsi organisasi Karang Taruna Damalawa sudah terlaksana dengan baik dengan diadakannya kegiatan rutin diantaranya rapat terbuka, kesenian dan olahraga yang berhasil mencegah dan mengurangi kenakalan remaja hinggah melahirkan prestasi. Mendukung program pemerintah desa dalam mengambangkan desa wisata, membantu pemerintah Desa dalam menyukseskan berbagai Pelatihan dan pendidikan, melakukan kegiatan Bakti sosial, dan terlibat langsung dalam memberikan bantuan langsung pada masyarakat yang membutuhkan.
\end{abstract}

\section{Kata Kunci: Fungsi, Organisasi Karang Taruna, Pelaksanaan Fungsi Organisasi Karang Taruna.}

\section{PENDAHULUAN}

Salah satu orgsnisasi yang ada di Indonesia yang aktif di dalam masyarakat Kelurahan/Desa yaitu Karang Taruna. Karang Taruna adalah organisasi sosial kemasyarakatan sebagai wadah dan sarana pengembangan setiap anggota masyarakat yang tumbuh dan berkembang atas dasar kesadaran dan tanggung jawab sosial dari, oleh dan untuk masyarakat terutama generasi muda di wilayah desa/kelurahan terutama bergerak dibidang usaha kesejahteraan sosial.

Dengan adanya Organisasi Karang Taruna dimaksudkan sebagai wadah untuk menampung aspirasi masyarakat, khususnya generasi muda dalam rangka mewujudkan rasa kesadaran dan tanggung jawab sosial terhadap masyarakat pada umumnya. Tujuannya tidak lain adalah terwujudnya kesejahteraan sosial yang semakin meningkatbagi generasi muda di Desa/Kelurahan yang memungkinkan pelaksanaan optimalisasi fungsional sebagai manusia pembangunan yang mampu mengatasi dan menanggulangi perubahan dan perkembangan global terhadap masalah kesejahteraan sosial di lingkungannya melalui usaha-usaha pencegahan, pelayanan dan pengembangan sosial. Pemuda desa diyakinan memiliki potensi untuk dapat menyelenggarakan kesejahteraan sosial karena pemuda sangat berperan penting dalam kehidupan desa karena itu karang taruna disebut sebagai 
sebuah wadah yang bertugas melakukan pembinaan dan pengembangan potensi generasi muda melalui usaha-usaha pencegahan, pelayanan dan pengembangan sosial. Berdasarkan uraian latar belakang masalah yang ada, maka penulis tertarik untuk melakukan penelitian dengan judul "Pelaksanaan Fungsi Organisasi Karang Taruna Damalawa Di Desa Tapuhaka Kecamatan Kabaena Timur"

\section{Organisasi Karang Taruna \\ Organisasi}

Michael J. Jucius (Sutarto, 2015:33). istilah organasasi disini dipakai untuk menunjukan pada suatu kelompok orang yang bekerja dalam hubungan yang saling bergantungan kearah tujuan atau tujuan-tujuan bersama. Sedangkan Joseph L. Massie (Sutarto, 2015:33). organisasi akan dirumuskan sebagai struktur dan proses kelompok orang yang bekerja sama membagi tugas-tugasnya di antara para anggota, menetapkan hubungan-hubungan, dan menyatuhkan aktivitas-aktivitasnya kearah tujuan-tujuan bersama.

Wasistiono (Rauf, dkk 2015:57), menyatakan bahwa manusia pada umumnya adalah makhluk organisasi (Homo organismus), artinya sejak manusia dalam kandungan sampai keliang lahat, manusia suka atau tidak suka, sengaja ataupun tidak sengaja akan berhubungan dengan organisasi. Dengan perkataan lain, organisasi memegang peranan penting dalam kehidupan manusia.

\section{Karang Taruna \\ Konsep Karang Taruna}

Peraturan Menteri sosial Republik Indonesia No.77 / HUK / 2010 tentang Pedoman Dasar Organisasi Pemuda Karang Taruna menjelaskan bahwa Karang Taruna adalah organisasi sosial kemasyarakatan sebagai wadah dan sarana pengembangan setiap anggota masyarakat yang tumbuh dan berkembang atas dasar kesadaran dan tanggung jawab sosial dari, oleh dan untuk masyarakat terutama generasi muda di wilayah desa/kelurahan terutama bergerak dibidang usaha kesejahteraan sosial".

Banyak hal yang bisa dilakukan oleh pemuda dalam organisasi Karang Taruna seperti disebutkan dalam Penjelasan lebih lanjut Peraturan Menteri Sosial No. 83 Tahun 2005 tentang Pedoman Dasar Karang Taruna sebagai berikut:

1. Melatih organisasi yang kompak dan sehat, ajang silaturahmi.

2. Mengadakan kegiatan kerja bakti kebersihan dan penataan lingkungan setiap minggu pagi.

3. Menggalakkan penanaman apotik hidup dan warung hidup disetiap halaman rumah warga.

4. Mengadakan jadwal pengajian dan olahraga bersama.

5. Mengadakan lomba hal-hal positif.

6. Mengadakan sekolah gratis untuk anak prasekolah yang tidak mampu.

7. Mendirikan perpustakaan sederhana setiap tahun diadakan acara wisata.

\section{Tujuan Karang Taruna}

Karang Taruna bertujuan untuk mewujudkan Pertumbuhan dan perkembangan setiap anggota masyarakat yang berkualitas, terampil, cerdas, inovatif, berkarakter serta memiliki kesadaran dan tanggung jawab sosial dalam mencegah, menangkal, menanggulangi dan mengantisipasi berbagai masalah kesejahteraan sosial, khususnya generasi muda; 
1. Kualitas kesejahteraan sosial setiap anggota masyarakat terutama generasi muda di desa/kelurahan secara terpadu, terarah, menyeluruh serta berkelanjutan;

2. Pengembangan usaha menuju kemandirian setiap anggota masyarakat terutama generasi muda; dan

3. Pengembangan kemitraan yang menjamin peningkatan kemampuan dan potensi generasi muda secara terarah dan berkesinambungan.

\section{Tugas Karang Taruna}

Karang Taruna memiliki tugas pokok secara bersama-sama dengan Pemerintah, Pemerintah Provinsi, dan Pemerintah Kabupaten/Kota serta masyarakat lainnya menyelenggarakan pembinaan generasi muda dan kesejahteraan sosial.

\section{Fungsi Karang Taruna}

Dalam melaksanakan tugas pokok sebagaimana dimaksud dalam Pasal 5, Karang Taruna mempunyai fungsi:

1. Mencegah timbulnya masalah kesejahteraan sosial, khususnya generasi muda;

2. Menyelenggarakan kesejahteraan sosial meliputi rehabilitasi, perlindungan sosial, jaminan sosial, pemberdayaan sosial dan diklat setiap anggota masyarakat terutama generasi muda;

3. Meningkatkan Usaha Ekonomi Produktif;

4. Menumbuhkan, memperkuat dan memelihara kesadaran dan tanggung jawab sosial setiap anggota masyarakat terutama generasi muda untuk berperan secara aktif dalam penyelenggaraan kesejahteraan sosial;

5. Menumbuhkan, memperkuat, dan memelihara kearifan lokal; dan

6. Memelihara dan memperkuat semangat kebangsaan, Bhineka Tunggal Ika dan tegaknya Negara Kesatuan Republik Indonesia.

\section{Pelaksanaan Fungsi Organisasi Karang Taruna Dalam Menyelenggarakan} Kesejahteraan Sosial

\section{Konsep Kesejahteraan Sosial}

Menurut Adi, (2012: 9) Kesejahteraan sosial ialah suatu tata kehidupan dan penghidupan sosial, materiil ataupun spiritual yang diliputi oleh rasa keselamatan kesusilaan, dan ketentraman lahir batin, yang memungkinkan bagi setiap warga Negara untuk mengadakan usaha pemenuhan kebutuhan-kebutuhan jasmaniah, rohaniah, dan sosial yang sebaik-baiknya bagi diri, keluarga serta masyarakat dengan menjunjung tinggi hak-hak serta kewajiban manusia sesuai dengan Pancasila".

Undang-Undang Republik Indonesia Nomor 11 Tahun 2009 Tentang Kesejahteraan Sosial pasal 1 bahwa Kesejahteraan Sosial adalah kondisi terpenuhinya kebutuhan material, spiritual, dan sosial warga negara agar dapat hidup layak dan mampu mengembangkan diri, sehingga dapat melaksanakan fungsi sosialnya. Penyelenggaraan Kesejahteraan Sosial adalah upaya yang terarah, terpadu, dan berkelanjutan yang dilakukan Pemerintah, pemerintah daerah, dan masyarakat dalam bentuk pelayanan sosial guna memenuhi kebutuhan dasar setiap warga negara, yang meliputi rehabilitasi sosial, jaminan sosial, pemberdayaan sosial, dan perlindungan sosial.

Dalam melaksanakan tugas pokoknya karang taruna mempunyai fungsi yang diatur dalam Peraturan Mentri Sosial Republik Indonesia Nomor 77 Tahun 2010 Tentang Pedoman Karang Taruna dalam pasal 5 mengatur bahwa karang 
taruna mempunyai fungsi; menyelenggarakan kesejahteraan sosial meliputi rehabilitasi, perlindungan, pemberdayaan sosial dan diklat setiap anggota masyarakat terutama generasi muda', .

\section{Rehabilitasi Sosial}

Rehabilitasi sosial adalah proses refungsionalisasi dan pengembangan untuk memungkinkan seseorang mampu melaksanakan fungsi sosialnya secara wajardalam kehidupan masyarakat. Rehabilitasi sosial sebagaimana dimaksud padaayat (1) dapat dilaksanakan secara persuasif, motivatif, koersif, baik dalam keluarga, masyarakat maupun panti sosial.

\section{Jaminan Sosial}

Jaminan sosial adalah skema yang melembaga untuk menjamin seluruh rakyat agar dapat memenuhi kebutuhan dasar hidupnya yang layak. Jaminan sosial diberikan dalam bentuk tunjangan berkelanjutan.

\section{Pemberdayaan Sosial}

Pemberdayaan sosial adalah semua upaya yang diarahkan untuk menjadikan warga negara yang mengalami masalah sosial mempunyai daya, sehingga mampu memenuhi kebutuhan dasarnya. Pemberdayaan sosial sebagaimana dimaksud padaayat (1) dilakukan melalui:

1. Peningkatan kemauan dan kemampuan;

2. Penggalian potensi dan sumber daya;

3. Penggalian nilai-nilai dasar;

4. Pemberian akses; dan/atau

5. Pemberian bantuan usaha.

\section{Perlindungan Sosial}

Perlindungan sosial adalah semua upaya yang diarahkan untuk mencegah dan menangani risiko dari guncangan dan kerentanan sosial. Perlindungan sosial dilaksanakan melalui:

1. Bantuan sosial;

2. Advokasi sosial; dan/atau

3. Bantuan hukum.

\section{Tujuan Penyelenggara Kesejahteraan Sosial}

Dalam Undang-Undang No 11 Tahun 2009 pasal 3 bahwa tujuan penyelenggara kesejahateraan sosial sebagai berikut :

1. Meningkatkan taraf kesejahteraan, kualitas dan kelangsungan hidup.

2. Memulihkan fungsi sosial dalam rangka mencapai kemandirian.

3. Meningkatkan ketahanan sosial masyarakat dalam mencegah dan menanganimasalah kesejahteraan sosial.

4. Meningkatkan kemampuan, kepedulian dan tanggung jawab sosial dunia usaha dalam penyelenggara kesejahetraan sosial.

5. Meningkatkan kualitas manajemen penyelenggara kesejahteraan.

\section{Fungsi-Fungsi Kesejahteraan Sosial}

Fungsi-fungsi kesejahteraan sosial bertujuan untuk menghilangkan atau mengurangi tekanan-tekanan yang diakibatkan terjadinya perubahan-perubahan sosio-ekonomi, mengindarkan terjadinya konsekuensi-konsekuensi sosial negatif akibat pembangunan serta menciptakan kondisi-kondisi yang mampu mendorong peningkatan kesejahteraan masyarakat. menurut Friedlander dan Apte (Adi, 2012:12) fungsi-fungsi kesejahteraan sosial tersebut adalah:

1. Fungsi Pencegahan (Preventive) 
Kesejahteraan sosial ditujukan untuk memperkuat individu, keluarga,dan masyarakat supaya terhindar dari masalah-masalah sosial baru.

2. Fungsi Penyembuhan (Curative)

Kesejahteraan sosial ditujukan untuk menghilangkan kondisikondisiketidakmampuan fisik, emosional, dan sosial agar orang yangmengalami masalah tersebut dapat berfungsi kembali secara wajardalam masyarakat.

3. Fungsi Pengembangan (Development)

Kesejahteraan sosial berfungsi untuk memberikan sumbangan langsungataupun tidak langsung dalam prosen pembangunan ataupengembangan tatanan dan sumber-sumber daya sosial dalammasyarakat.

4. Fungsi Penunjang (Supportive)

Fungsi ini mencakup kegiatan-kegiatan untuk membantu mencapaitujuan sector atau bidang pelayanan kesejahteraan sosial.

\section{METODE PENELITIAN}

\section{Lokasi dan Waktu Penelitian}

Penelitian ini dilaksanakan di Karang Taruna yang berada di Desa Tapuhaka Kecamatan Kabaena Timur. Alasan pemilihan lokasi, karena pemuda yang berada di Desa Tapuhaka memiliki potensi yang besar dalam berupaya menyelenggarakan kesejahteraan sosial.Penelitian ini dilaksanakan pada bulan maret sampai bulan April 2019.

\section{Jenis dan Pendekatan Penelitian}

Jenis penelitian ini adalah penelitian deskriptif dengan pendekatan kualitatif yaitu menggambarkan dan menjelaskan tentang bagaimana pelaksanaan fungsi Organisasi Karang Taruna Damalawa dalam menyelenggarakan kesejahteraan sosial.

\section{Responden dan Informan Penelitian}

1. Responden, dalam penelitian ini adalah ketua karang taruna dan anggota karang taruna yang berjumlah 11 orang.

2. Informan, dalam penelitian ini yaitu kepala desa dan 2 tokoh masyarakat yang beralamat di Desa Tapuhaka Kecamatan Kabaena Timur.

\section{Teknik Pengumpulan Data}

Teknik pengumpulan data merupakan cara yang dilakukan peneliti untuk mengungkup atau menjarinya infomasi kualitatif dari responden sesuai lingkung penelitian.

Dalam penelitian ini ada beberapa jenis pengumpulan data yang digunakan penulis yaitu:

1. Observasi (pengamatan) yaitu mengamati atau menyaksikan secara langsung bagaimana pelaksanaan fungsi organisasi Karang Taruna Damalawa dalam menyelanggarakan kesejahteraan sosial.

2. Wawancara,yang merupakan metode pengumpulan data dengan cara bertanya langsung kepada responden, dalam hal ini ketua karang taruna, anggota karang taruna dan Kepala Desa Tapuhaka Kecamatan Kabaena Timur.

3. Dokumentasi, digunakan untuk menemukan informasi yang akurat, dengan melakukan pencatatan, pengambilan foto dan pengumpulan beberapa dokumen yang mendukung tentang bagaimana pelaksaanaan fungsi organisasi karang 
taruna damalawa dalam menyelenggarakan kesejateraan sosial di Desa Tapuhaka Kecamatan Kabaena Timur.

\section{Teknik Analisis Data}

Teknik analisis data diartikan sebagai upaya data yang sudah tersedia kemudian diolah dengan statistic dan dapat digunakan untuk menjawab rumusan masalah dalam penelitian (Sujarweni, 2014:103). Teknik analisis data yang digunakan dalam penelitian ini adalah model interaktif dari Miles dan Huberman (Sugiyono, 2016:334-343) dengan tiga komponen yaitu :

1. Reduksi Data (Data Reduction)

Reduksi data (Data Reduction) merupakan bagaian dari analisis data yang mempertegas, memperpendek, membuat fokus, membuang hal-hal yang tidak penting dan mengatur data sedemikian rupa sehingga kesimpulan penelitian dapat dilakukan.

2. Penyajian Data (Data Display)

Penyajian Data (Data Display) merupakan rakitan organisasi informasi, deskripsi dalam bentuk narasi yang memungkinkan kesimpulan penelitian lebih mudah atau dapat di lakukan.

3. Penarikan Kesimpulan dan Verifikasi (Conclusion Drawing/Verification)

Dari sajian data yang telah disusun kemudian dapat dilakukan penarikan kesimpulan, yaitu kegiatan merumuskan kesimpulan yang dapat diverifikasi selama penelitian sedang berlangsung sehingga dapat diuji kesimpulan yang diambil lebih kokoh dan lebih akurat.

\section{HASIL dan PEMBAHASAN}

\section{Pelaksanaan Fungsi Organisasi Karang Taruna Damalawa DalamMenyelenggarakan Kesejahteraan Sosial}

Pelaksanaan fungsi organisasi karang taruna di atur di dalam Peraturan Menteri sosial Republik Indonesia No.77 / HUK / 2010 tentang Pedoman Dasar organisasi pemuda karang taruna didalam pasal 5, dalam mengembang tugasnya karang taruna memiliki fungsi: Menyelenggarakan kesejahteraan sosial meliputi rehabilitasi, perlindungan sosial, jaminan sosial, pemberdayaan sosial dan diklat setiap anggota masyarakat terutama generasi muda.

Pelaksanaan fungsi organisasi karang taruna Damalawa dalam upaya menyelenggarakan kesejahteraan sosial di Desa Tapuhaka Kecamatan Kabaena Timur diraikai dalam berbagai kegiatan-kegiatan atau aktifitas pemuda diantaranya:

\section{Rehabilitasi}

Rehabilitasi sosial adalah proses refungsionalisasidan pengembangan untuk memungkinkan seseorang mampu melaksanakan fungsi sosialnya secara wajar dalam kehidupan masyarakat rehabilitasi yang dilakukan Karang Taruna Damalawa untuk mencegah timbulnya masalah sosial dan agar pemuda yang melakukan penyimpangan sosial seperti kenalakan remaja dapat kembali melaksanakan fungsi sosial dalam kehidupan masyarakat dengan baik dan bertanggung jawab. Dengan diberlakukannya rutin kegiatan kesenian dan kegiatan olahraga dimaksudkan untuk melahirkan aktifitas yang positif bagi para pemuda desa sehinggah dipercaya dapat mencegah dan mengurangi dampak kenalan remaja. 
Dari data yang diperoleh dalam metode wawancara mendalam terdapat beberapa kegiatan Karang Taruna Damalawa dalam berupaya menyelenggarakan kesejahteraan sosial yang meliputi rehabilitasi dengan menjalakan kegiatan anataranya:

\section{Rapat Terbuka}

Rapat tebuka Diadakan rutin setiap bulannya disetiap tanggal 12 Bertempat di rumah ketua Karang Taruna, rapat ini tidak bersifat rahasia dan boleh dihari oleh semua orang yang ingin berpartisipasi dengan Agenda rapat membahas kebersihan lingkungan, peningkatan keamanan. dalam mengadakan suatu kegiatan dalam mengembang tugasnya sebagai organisasi kemasyarakatan yang berada didesa. Sebelum melakukan kegiatan Karang Taruna Damalawa melakukan rapat terbuka untuk membahas kegiatan yang terarah.

\section{Kegiatan Kesenian}

Selain kegiatan rapat terbuka Karang Taruna Damalawa juga mengaktifkan anggotanya untuk selalu mencintai kebudayaan lokal, kesenian dengan berbagai kegiatan diantaranya melakukan pentas seni dan tari lumense, kegiatan kesenian ini bersifat umum yang dapat diikuti oleh semua masyarakat yang ingin berpartisipasi, kegiatan latihan pentas seni dilaksanakan 1 bulan sebelum hari raya idul fitri. Berbeda halnya dengan kegiatan kesenian tari lumene latihan baru akan dilaksanakan 1 bulan sebelum perlombaan dalam rangka memperingati hari kemerdekaan Republik Indonesia ditingkat Kecamatan. Kegiatan kesenian yang dilakukan Karang Taruna Damalawa dirangkai dengan beberapa kegiatan diantaranya pentas seni dan tarian lumensi, kegiatan tersebut sengaja dilakukan untuk melatih, membimbing dan menanamkan aktifitas yang positif dikalangan pemuda desa Tapuhaka sehingga dapat mencegah dan menanggulangi kenakalan remaja.

\section{Kegiatan Olahraga}

Kegiatan olahraga yang dilakukan Karang Taruna Damalawa berupa bola voli yang dilakukan rutin setiap harinya di lapangan voli desa Tapuhaka kegiatan ini dilakukan selain hobi juga untuk mempersiapkan diri dalam rangka mengikuti perlombaan di tingkat desa maupun kecamatan. Tidak ada keterlibatan perempuan dalam kegiatan olahraga yang rutin dilakukan disore hari. Kegiatan olahraga dilakukan oleh Karang Taruna Damalawa bertujuan untuk melatih dan membimbing para anggota agar tumbuh aktifitas positif para anggota dalam mengembangkan bakat dan potensi pemuda di dalam kegiatan, kegiatan tersebut dibentuk karena hobi bermain bola voli dan juga segaja diadakan untuk mempersiapkan diri mengikuti perlombaan baik ditingkat desa maupun ditingkat kecamatan.

\section{Pemberdayaan Sosial}

Pemberdayaan sosial adalah semua upaya yang diarahkan untuk menjadikan warga negara yang mengalami masalah sosial mempunyai daya, sehingga mampu memenuhi kebutuhan dasarnya. Karang Taruna Damalawa ikut melakukan pemberdayaan sosial yang dilaksanakan dengan upaya yang diarahkan untuk menjadikan masyarakat Desa Tapuhaka yang mengalami masalah sosial mempunyai daya, sehingga mampu memenuhi kebutuhan dasarnya.Pemberdayaan sosial dilakukan dalam bentuk: 


\section{Pengembangan Desa Wisata}

Peluang usaha modal kecil untung besar didesa terpencil adalah jenis usaha yang sedang didorong pemerintah. Usaha jenis ini biasanya justru berkait dengan potensi unik desa terpencil misalnya potensi alam yang jarang dimiliki desa-desa diwilayah lain. Seperti halnya didesa Tapuhaka yang memiliki pulau Damalawa yang berada didepan dusun bungitowea dengan jarak tempuh 2 menit mengunakan perahu laut. Pulau Damalawa dijadikan sebagai obyek desa wisata pulau Damalawa Desa Tapuhaka dengan tujuan untuk mendongkrak pendapat sendiri desa Tapuhaka. Desa wisata pulau damalawa desa tapuhaka merupakan BUMDes "Usaha baru" adalah Badan Usaha Milik Desa yang dimiliki oleh pemerintah Desa dan masyarakat dengan komposisi kepemilikan mayoritas oleh pemerintah Desa.BUMDes "Usaha Baru" berfungsi sebagai lembaga ekonomi Desa yang mengembangkan usaha dalam rangka mewujudkan kesejahteraan masyarakat khususnya rumah tangga miskin DesaTapuhaka.

Karang Taruna Damalawa mendukung program Kepala Desa Tapuhaka melaksanakan pengembangan desa wisata pulau Damalawa desa Tapuhaka. Kegiatan ini dimaksudkan yaitu menggali potensi sumber daya alam Pulau Damalawa dengan kegiatan rutin yang dilaksanakan setiap minggu dengan agenda menjaga kebersihan dan memperindah pulau damalawa. Dengan adanya organisasi Karang Taruna Damalawa mendukung kegiatan Kepala Desa Tapuhaka dalam berbagai upaya membantu mengembangkan desa wisata pulau Damalawa yang sekarang terwujud menjadikan pulau tersebut sebagai wisata Desa Tapuhaka.

\section{Perlindungan Sosial}

Perlindungan sosial adalah semua upaya yang diarahkan untuk mencegah dan menangani risiko dari guncangan dan kerentanan sosial. Perlindungan sosial oleh Karang Taruna dilaksanakan melalui: Dari hasil penelitian yang diperoleh melalui metode observasi, wawancara dan dokumentasi ada berbagai kegiatan yang dilakukan oleh Karang Taruna Damalawa salah satunya yang paling sering dilakukan adalah sebagai berikut:

\section{Bakti Sosial}

Bakti sosial yang dilakukan karang taruna Damalawa merupakan salah satu kegaitan yang paling sering dilakukan dengan jadwal rutin setiap minggu membersihkan lingkungan seperti: jalan raya, TPU, masjid, bendungan dll. Kegiatan Bakti sosial yang dilakukan pemuda yang tergabung didalam Organisasi Karang Taruna Damalawa sudah menjadi kegiatan rutin yang dilakukan seminggu sekali bertujuan untuk menjaga kebersihan lingkungan Desa Tapuhaka.

\section{Bantuan Langsung}

Bantuan langsung yang dilakukan oleh Karang Taruna Damalawa berupa bantuan tenaga dan mendistribusikan bantu oleh Karang Taruna Damalawa dari masyarakat untuk masyarakat yang membutuhkan bantuan.Kegiatan pemberian bantuan berupa tenaga dilaksanakan oleh anggota Karang Taruna Damalawa dengan membantu masyarakat yang sedang mengadakan acara seperti membantu mendirikan tenda, mengumpulkan kursi, piring dan membantu menyebarkan undangan, membantu masyarakat memindahakan rumah, menggali kubur dll.

Kegiatan membantu masyarakat yang aktif dilakukan pemuda-pemudi yang tergabung diKarang Taruna Damalawa telah mengugurkan beban yang timbul dalam masyarakat, kegiatan ini sudah menjadi keharusan yang harus dijunjung tinggi pemuda-pemudi desa. Kegiatan tersebut menunjukan adanya kesadaran 
sosial yang cukup tinggi dikalangan pemuda. Kegiatan kerja bakti dan kegiatan memberikan bantuan langsung yang dilakukan Karang Taruna Damalawa bertujuan untuk membantu masyarakat memenuhi kebutuhan dasar yang layak berupaya meringankan beban masyarakat, mencegah dan menangani risiko dari guncangan kerentanan sosial.

\section{Diklat Setiap Anggota Masyarakat Terutama Generasi Muda}

Diklat setiap anggota masyarakat terutama generasi muda adalah sebuah upaya dalam mengembangkan sumberdaya manusia terutama untuk mengembangkan kemampuan intelektuan dan kepribadian manusia.

Kegiatan diklat yamg dilakukan Pemerintahan Desa Tapuhaka didukung dengan partisipasi pemuda Karang Taruna Damalawa yang bergerak aktif sebagai panitia pelaksana pelatihan perbengkelan dan pelatihan manajemen perekonomian yang dilaksanakan pada tahun 2019, kegiatan pelatihan ini dibuka untuk masyarakat yang berusia 18 - 40 tahun, kegiatan pelatihan perbengkelan dihadiri oleh 37 anggota masyarakat sedangkan Pelatihan manajemen perekonomian dihadiri oleh 63 peserta anggota masyarakat. Pelaksana pelatihan oleh Pemerinthan Desa Tapuhaka, Karang Taruna Damalawa bergerak sebagai panitia pelaksana pelatihan. Pemberian pelatihan dan pembinaan yang dilakukan pemerintahan Desa Tapuhaka dilakukan dengan baik dengan tujuan untuk melahirkan pemuda yang mandiri dan bertanggung jawab sehingga diharapkan dapat berguna di dalam bermasyarakat. Kehadiran Karang Taruna Damalawa sebagai panitia pelaksana yang bertujuan meringankan tugas Kepala Desa Tapuhaka.

Kesejahteraan sosial merupakan keadaan dimana seseorang merasa nyaman, tentram, bahagia, serta dapat memenuhi kebutuhan hidupnya, ini sejalan dengan fungsi Karang Taruna dalam mengembang tugasnya menyelenggarakan kesejahteraan sosial, melakukan pencegahan dan menanggulangi masalah sosial yang hadir baik perseorangan maupun kelompok masyarakat.

\section{PENUTUP}

\section{Kesimpulan}

Berdasarkan hasil penelitian dan pembahasan, maka dapat disimpulkan bahwa pelaksanaan fungsi Organisasi Karang Taruna Damalawa di Desa Tapuhaka Kecamatan Kabaena Timur sudah terlaksana dengan baik, dengan diadakannya kegiatan rutin diantaranya rapat terbuka,kesenian dan olahraga yang berhasil mencegah dan mengurangi kenakalan remaja hinggah melahirkan prestasi. Mendukung program pemerintah desa dalam mengambangkan desa wisata, membantu pemerintah Desa dalam menyukseskan berbagai Pelatihan dan pendidikan, melakukan kegiatan Bakti sosial, dan terlibat langung dalam memberikan bantuan langsung pada masyarakat yang membutuhkan.

\section{Saran}

Berdasarkan simpulan penelitian, maka diajukan saran kepada

1. Karang Taruna Damalawa, untuk selalu menjaga kekompakan dan keakraban antara anggota maupun warga setempat, menjunjung tinggi kesadaran sosial untuk selalu menciptakan generasi yang bertanggung jawab sehingga diharapkan dapat berguna untuk bangsa dan Negara.

2. Pemerintah, sebaiknya lebih memprioritaskan pengembangan potensi pemuda desa dengan memberikan beasiswa kepada pemuda Desa Tapuhaka untuk terus 
mengembangkan potensi yang mereka miliki sehingga dapat berguna untuk bangsa dan Negara.

3. Bagi seluruh masyarakat desa diharapkan agar selalu menunjukkan dukungannya pada Organisasi Karang Taruna Damalawa dengan berpartisipasi aktif dalam berbagai kegiatan yang mereka adakan. Harus selalu menjaga dan mempertahankan serta melestarikan gotong royong sebagai suatu budaya yang dapat bermanfaat.

\section{Daftar Pustaka}

Adi, Fahrudin. 2012. Pengantar Kesejahteraan Sosial, Bandung: Refika Aditama.

Peraturan Mentri Sosial Republik Indonesia Nomor 83 Tahun 2005 Tentang Pedoman Karang Taruna

Peraturan Mentri Sosial Republik Indonesia Nomor 77 Tahun 2010 Tentang Pedoman Karang Taruna

Rauf, Rahyuni, dkk. 2015. Lembaga Kemasyarakatan Di Indonesia, Pekanbaru:Zanafa Publishing.

Sujarweni, Wiratna. 2014. Metodologi Penelitian. Yogyakarta: Pustakabarupres

Sugiyono. 2016. Metode Penelitian Kuantitatif, Kualitatif dan Kombinasi (mixed Methods). Bandung: Alfabeta.

Sutarto. 2015. Dasar-Dasar Organisasi, Yogyakarta: Gadjah Mada University Press.

Undang-Undang Republik Indonesia Nomor 11 Tahun 2009 Tentang Kesejahteraan Sosial. 